Leonardo Fernando Cruz Basso ${ }^{1}$

\title{
SAVING THE EURO: CREATING SOCIAL REGIONAL CURRENCIES, TAXES ON FINANCIAL TRANSACTIONS, AND MINIMUM INCOME PROGRAMS
}

\begin{abstract}
This paper proposes the creation of regional currencies, which we call social currencies (pesetas, dracmas, liras; deutsche mark) with the finality of financing minimum income programs and microfinance programs in Europe. The backing for this currency will be Euros collected based on the creation of taxes on regional financial transactions. Depending on the tax rate the amount of money collected can be substantial and can be used to buy to buy government bonds of countries with severe funding problems.
\end{abstract}

\section{Keywords}

Basic income, Minimum income, Quantity theory of money, Social currencies, Taxes on regional financial transactions, Tobin tax

\section{Introduction}

In all the proposals that we have read so far to solve the European crisis, not one submitted what we believe to be an essential element: the creation of regional currencies, which we call social currencies; the name could be better but what we have in mind with this name is that this currency includes an essential social component, which is job creation; there is nothing new with alternative currencies that circulate side by side with the national currencies of countries with monetary problems, and this has already occurred in Brazil with the creation of social currencies of restricted circulation, as well as in Argentina, when the population lost its confidence in a currency subjected to ongoing and significant devaluations.

These currencies should reflect three features: the first is that the exchange rate should devalue against the euro, as one of the latter's problems is that it prevents competition by countries with less productivity, as we have already argued in an article (Basso, 2005) on exchange rate parities (criticizing the Brazilian real/US dollar exchange rate which was at the origin of the real plan); the second is that these currencies are of a transitory nature and will become extinct when economic conditions improve in European countries; the third is that as opposed to what happened in countries that created social currencies (where creation and emissions were private) creating and issuing will be under the control of central banks in order to prevent counterfeiting and unrestricted emissions.

\footnotetext{
${ }^{1}$ Universidade Presbiteriana Mackenzie (PPGAE-Mackenzie), Brazil, e-mail: leonardobasso@mackenzie.br; leonardofernandbasso@terra.com.br
} 
The backing for this currency will be Euros collected based on the creation of taxes on regional financial transactions. We put forth a similar proposal in a previous article but our concern in that text was to collect funds in order to put in place a minimum income program for those people affected by unemployment; currently the focus is another, as the social currency is intended to reactivate the economy as well as to fund a minimum income. The second essential component in our proposal is the creation of a minimum income for those affected by unemployment; this minimum income would be funded by social regional currencies, issued in accordance with each country's needs; this would not be inflationary for two reasons: recent events in the United States have raised a query on the expertise of defenders of the quantity theory of money (significant emissions do not result in significant inflation); frugal emissions give rise to product increases (consumer goods in this case).

The second essential component in the proposal is the introduction of regional financial transaction taxes, because we have found that countries such as England will veto the creation of a Tobin tax for the whole of Europe; this tax, as found when implementing the CPMF (provisional contribution on financial transactions) tax in Brazil, has an excellent collection potential depending on the tax rate, and may provide funds to partially remedy problems with budgetary deficits, reducing the debt/GDP ratio to satisfactory levels. The Brazilian experience shows that there is nothing destabilizing about enforcing this tax.

Implementing this tax should form part of a broader proposal to regulate financial resources in European countries (the most appropriate expression would be regulation of financial resources), as the very much commented solution for the social welfare state did not occur.

\section{Diagnosis}

Replacing national currencies by Euros was one of the European Union's relevant events, as it allowed countries to prepare a group of policies to preserve the currency's stability, while at the same time avoiding the detrimental effects of solving problems at the expense of neighbors. Nonetheless, the fact that there are economies with different productive bases (such as Germany, one of the world's most powerful economies, and Greece, which depends on its agricultural base) leads to productivity being widely different and affecting competitiveness in a number of fields in different nations. This fact has led nations to use the public sector to solve short-term problems, forgetting that only a competitive productive base will be a definite solution for their problems. Recurring public deficits to drive the economy will always charge a price if they are not followed in the long run by an increase in the government's tax basis, as has occurred now; moreover, this increase can take place only if the economies are able to compete to create revenues. This is equal to wishful thinking if the economies do not work in improving productivity, which can only take place by changing the productive base and with recurring investments.

\section{The proposal}

Let us assume that a country has income that can be spent by consumers, equal to 100 Brazilian Reais per annum. 
Let us also suppose that circulating this income through banks could result in the public sector collecting 10 Brazilian Reais per annum as contributions on financial transactions (a simplified version of the Tobin tax). This contribution is nothing more than the provisional contribution on financial transactions (CPMF) that existed in Brazil's and Argentina's tax systems; the provisional contribution on financial transactions could be converted into a permanent contribution on financial transactions (we will preserve the same acronym to name the permanent contribution).

Let us assume that in order to back all of this anti-hunger currency, from now on named citizenship currency, the CPMF would be adopted, and the most that the government could print in this currency would be 10 Brazilian Reais, in other words, a monetary unit of the citizenship currency would be equal to one unit of Brazilian currency, the real.

Table 1 illustrates what would happen, proving that no currency would be created. As the poorer people do not have bank counts, this plan is certainly an income reallocater.

We will describe in detail the process's complete steps. To begin with, the Government will issue the equivalent of 10 Reais in citizenship currency and transfer (1) to the impoverished (although this is an important discussion topic, it is not in our scope here to discuss which of the poor will have priority treatment; the issue is complex, as an individual with a scarce income may be in worse condition than an individual not connected to the market economy, such as an Indian or an inhabitant of the Amazon region who makes a living from natural resources).

The sum transferred in this first plan should be equal to the sum collected through the permanent contribution on financial transactions (CPMF). 


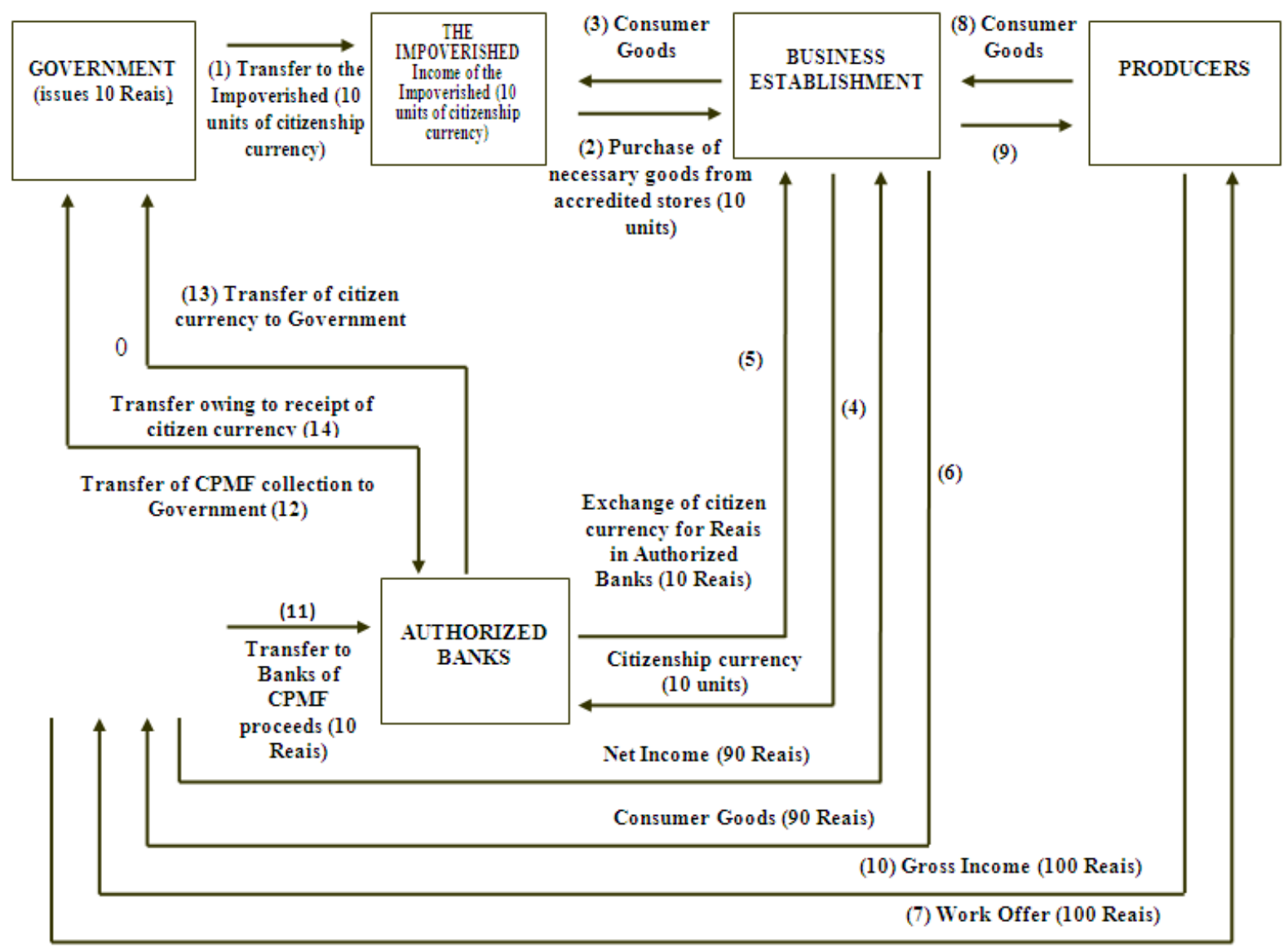

Figure 1: Issuing and Circulating Social (Citizenship) Currency (Basso)

In order to simplify, we will assume that one unit of citizenship currency is equal to one real. To start with, this currency could be spent on food only (this assumption will discarded further on, with an argument in favor of expenditures with consumer goods, whether or not durable, or even any other kind of goods).

The unemployed having in hand a sum due to them will go to stores that sell food, (2) which would retain the food currency while at the same time transferring consumer goods to the unemployed (3). These stores will exchange the citizenship currency for CPMF tax collection in financial institutions (4) and (5).

The population with income, which at the start had 100 Reais in income, now has available 90 Reais with this income's financial transactions and the taxation on it (CPMF). The population uses up the 90 Reais in consumer goods in the retail stores (6).

The population's income originates from the provision of work to producers totaling 100 Reais (7), who produce consumer goods totaling 100 Reais. The reader, who was brought up under the principles of a classic economy, might inquire why we omitted the creation of value in production, one of the greatest discoveries of classic economists. This was done in order to simplify the reasoning, but no producer would produce if the value going into the productive process is the same resulting from the same process.

Producers sell consumer goods totaling 100 Reais to retail stores (8) and receive 100 Reais, (9) which is used to pay for the work by the population with income (10). 
The banks will be in charge of retaining the CPMF funds due by the population (11).

They transfer to the Government the citizenship currency obtained from the retailers (13) at the same time that they transfer the CPMF funds to the government (12) and receive 10 Reais for transferring to it the citizenship currency (14).

Under the proposed plan, the only two unilateral transfers take place between the Government and the impoverished, and the population and the banks.

For all other transfers the path has two ways, i.e.: money is transferred from one point to another in the system, at the same time that goods or work are involved in the opposite direction.

Money issued by the Government, which is equal to creating legal tender, is offset by withdrawing income from the population through the CPMF.

It could be argued that as the money was issued before taxation, there is a likelihood that this plan is inflationary, but in truth taxation occurs during the same time span as issuing, so offsetting exists.

Albeit the currency emission is prior to taxation of the population, increased expenditure due to the excess currency (equal to 110 Reais) giving rise to a price increase, would be offset by a subsequent downturn in demand for money (equal to 100 Reais), leading to a decline in prices.

This first plan is extremely stringent, forcing retail stores to go to the banks to exchange citizenship currency for CPMF funds. This would avoid the creation of legal tender.

A milder alternative may be visualized in the structure of the "barter market" in Buenos Aires. This market, not really a barter market, arose as a result of the crisis that has overcome Argentina, where the unemployed need to exchange what they produce over a period (flow of wealth produced) and even a part of their acquired wealth (stock of acquired wealth) in order to meet their basic needs (an expression with a connotation broader than satisfying hunger). Each participant in this market receives a number of credits, depending on what he/she has to offer.

With these credits in hand, the person will search for the goods required, validating with payment (using credits) the private labor embodied in other goods.

As the credits are widely accepted and can validate private labor, they serve as a general equivalent and are therefore legal tender. The difference of what occurs in this market and the use of citizenship currency in the first plan is that now validation is broader, including not only wealth produced over the period but inventories from previous periods, which raises the question of what would happen with the citizenship currency's value in connection with the Argentine peso (or the real if the plan were to be introduced into Brazil). 
In Argentina's case, the "barter market" has already replied.

One credit unit is worth two pesos, confirming in fact what economists who believe in productivity as the exchange rate's determining factor have already demanded for a long time: The peso's devaluation vis-à-vis the US dollar.

We would not run the risk of increasing the discount, producing inflation in the citizenship currency.

Not if the number of credits (i.e.: the citizenship currency) can be kept under control and regularly exchanged in banks, in accordance with a discount specified by the market. If the goods could be exported, the discount would make the goods produced for bartering more attractive than those in the formal economy, quoted in Argentine pesos. A third more daring plan consists in the creation of a citizenship currency and allowing loans to be made in this currency, provided that they were granted under micro-credit programs, to expand the supply of food. We can use Milton Friedman's argument to demonstrate why this plan is not inflationary.

\section{Several comments on the quantity theory of money}

The simplest version of the quantity theory of money may be expressed as: $M * V=P * Y$ In which:

$M=$ stock of means of payment, i.e.: paper money in the public's possession plus its sight deposits in commercial banks.

$v=$ the currency's velocity of circulation

$\mathrm{P}=$ a price index, and in the case of the entire economy, the product's implicit deflator

$Y=$ index for real product

This equation may be converted into a dynamic equation representing variations in time.

The variables may be named:

$$
\begin{aligned}
& \Delta M / \Delta t \cdot 1 / M=\vec{M} \\
& \Delta P / \Delta t \cdot 1 / P=\hat{P} \\
& \Delta Y / \Delta t \cdot 1 / Y=\hat{Y} \\
& \Delta v / \Delta t \cdot 1 / v=\hat{v}
\end{aligned}
$$

And considering a constant velocity of circulation, we will have the equation:

$$
\begin{gathered}
\widehat{M}+\hat{v}=\widehat{P}+\widehat{Y} \\
\widehat{M}=\widehat{P}+\widehat{Y}
\end{gathered}
$$


Based on the scenario expressing the relation between gross domestic product and the amount of currency required to achieve this, we can devise at least five theories.

Three theories are devised based on the additional assumption that the velocity of circulation is constant and that the cause of inflation is an increase in the volume of money in the economy (the currency is the root of price rises).

The first of these, which we might name short-term Friedmanian, provides that the additional stock of currency will be divided between a price rise and an increase in real product. Acting prudently, the volume of currency may be increased in the same proportion as real product estimated growth. This increase may be provided by social (beneficial) currency. We might argue that short-term growth will not imply inflationary pressures if expenditures come together with increases in the gross formation of fixed capital, creating additional goods and services.

The second theory, which we might name Keynesian recessionary, upholds that an increase in supply will impact real growth only, as in depressed economies the monetary stimulus will not produce inflation as the first reason is to recover the economy from a depression (or recession). There is a parallel between this theory and what is currently happening in Europe and the United States, with massive currency emissions to recover both continents from a recession. As upheld by the Keynesian theory, expressive currency emissions may not impact on product should the process occur known as the liquidity trap. Even when unrestricted currency is available, families will not spend should they feel a threat of losing their jobs during a recession, and businessmen will not invest if they do not foresee generous times ahead to sell the goods resulting from their investments.

The third theory applies to situations in which the economy uses a significant enough portion of productive capacity and is close to full employment. In this situation, increases in the supply of currency will result in price rises as it is not possible to increase product.

A fourth version of the quantity theory assumes that the chief cause of price rises is a currency increase, but changes the velocity of circulation. This seems to be the expectation by the US, expressive increases in the volume of currency are not being converted into inflation, due to a change in the currency's velocity of circulation in a direction opposed to the increase in the volume of currency.

Under the same scenario, there are two more theories that change this cause and effect relation. We might name them Marxist and Keynesian.

In both of them, increases in the volume of currency arise from price rises and greater quantities.

Keynesian theories explain prices with mark-up theories. Once mark-ups and quantities for production are decided, products ( gross domestic products) will be determined (prices multiplied by amounts). Products determine the volume of currency to realize them. Should the amount of currency be sufficient to make products, the velocity of circulation will not change. Should the amount of currency prove insufficient, the velocity of circulation will rise. 
Should the amount of currency be excessive, this will affect the currency's velocity of circulation. What distinguishes Marxists from Keynesians is the micro-economic theory that explains price levels, with Marxists adopting the labor theory of value and Keynesians using the surplus theory based on goods (Sraffa) or the utility value theory.

In summary, there are several theories advocating that an increase in the amount of currency is not inflationary, and these theories support the creation of social (beneficial) currency.

\section{The Tobin tax}

The funds for a stricter plan of creating a social currency (without issuing any amount of currency) would originate from a Tobin tax.

There are a number of versions of a tax on financial transactions, implying various amounts in proceeds. One version involves taxation of foreign exchange markets (Kapoor, 2004). Our purpose here is not to discuss the best form of taxation on currency transactions, but to argue in favor of a successful one, the CPMF's effectiveness in Brazil with a relevant collection of funds. The CPMF is a tax applied to any financial transaction within the country. The volume of funds collected may be significant depending on the tax rate, with the advantage of not requiring international agreements to be enforced. As England did not enact the Tobin tax, the solution is found in domestic CPMFs. This tax is certainly regressive, as its rate is incident on all income brackets. I uphold that this tax is of a nature that supplants the disadvantage of a regressive nature, with its implicit dimension of solidarity; all of a country's inhabitants should be granted the means of eliminating hunger, and this is a task for all of a country's inhabitants.

\section{The use of money}

Tobin's initial proposal was to reduce the volatility of international capital flows, considered in the past to be destabilizing (Basso, Pinho and Silva, 2001).

We now know that capital flows are much more difficult to control when the prospects of returns are spectacular. We give an example: one of the explanations for the sub-prime crisis in the United States sustains that the huge deficits in the US balance of payments caused the crisis. The huge deficits led to incoming funds by means of the capital account, which led to growing investments, consumer spending, and indebtedness by families at levels not compatible with a balanced position.

We can foresee expenditures of the Tobin tax in numerous activities, depending on the problem we wish to grasp.

a. implementation of a minimum income program: countries suffer the impact of crises in different manners; Spain is undergoing extremely high unemployment rates; in this case the proceeds would be allocated to minimum income programs; 
b. incentives to change the energy matrix: some forms of energy are deemed to be too expensive; an example is solar energy; some countries such as China are able to produce equipment for using this form of energy much more cheaply than those produced in western countries; the funds would be employed to subsidize acquisition of this equipment, still considered expensive; these funds could also be employed to produce this equipment in western countries at prices subsidized by the Tobin tax;

c. micro-credits to organize small businesses: minimum income is effective over consumer activity; an alternative is to encourage the formation of gross investment capital by small entrepreneurs, with a view to job creation;

d. changes in transport infrastructure: this is an extremely necessary use of funds in emerging countries such as Brazil (and other Latin American countries), which ignored railway transportation.

I will explain with an example. Table 1 reflects a series of revenues that we deem relevant to fund railroad transportation (taken from an end-of-course paper by Karine Bincoletto (2010). The first column shows current revenues for two metropolitan regions in the state of São Paulo (Campinas and São Paulo). As these are two very populous regions, the sums would be employed to fund the railroad system in these regions. The percentage in question will be $1 \%$.

The second column reflects taxation on motor vehicles. As vehicles contribute to degrade air quality, the percentage in question will be $10 \%$.

The third column refers to revenues from the state of São Paulo's value-added tax (ICMS tax). As the railroad system produces positive externalities, $1 \%$ of the entire state's revenues will be allocated to build the system in two regions. The fourth column shows a Brazilian version of the Tobin tax (CPMF - provisional contribution on financial transactions). In Brazil the tax rate was high (0.38\%) and we allocated $21 \%$ to build the railroad system, which represents the state of São Paulo's share in Brazil's population.

An alternative step was the idea of using a portion of the state of São Paulo's IPVA (motor vehicle tax) revenues to reactivate railways. The idea is to allocate $10 \%$ of this tax to build the São Paulo - Campinas railroad. As for the ICMS tax collected in the state of São Paulo, 1\% of its value will be employed in the construction. With regard to the ICMS tax, a sum was calculated to be allocated to the state of São Paulo if the criterion were based on population. And by means of the figures found, it is possible to calculate how many kilometers could be built by means of these three methods.

\begin{tabular}{|c|c|c|c|c|}
\hline & $\begin{array}{c}\text { CURRENT } \\
\text { REVENUES* }\end{array}$ & IPVA** & ICMS*** & CPMF**** \\
\hline TOTAL & $42,463,513,954$ & $8,789,600,000$ & $77,202,300,000$ & $36,483,000,000$ \\
\hline PERCENTAGE & $424,635,140$ & $878,960,000$ & $772,023,000$ & $7,661,430,000$ \\
\hline
\end{tabular}

* $1 \%$ of current revenues by the municipalities in the metropolitan region of São Paulo and Campinas for $2008 ; * * 10 \%$ of the sum collected by the state of São Paulo for 2009; *** $1 \%$ of the sum with regard to the state of São Paulo for 2009; **** sum equal to $21 \%$ of the total CPMF, the state of São Paulo's percentage share in the country' population.)

Table 1: Percentage of sums from sources of funding - (data in Brazilian Reais for 2008; Bincoletto and Simone, 2010) 
Table 2 demonstrates costs per km of three kinds of railway transportation, monorail, light rail vehicle, and high-speed train.

\begin{tabular}{|c|c|}
\hline \multicolumn{2}{|c|}{ COST PER KM } \\
\hline MONORAIL & R\$ 75 MILLION \\
\hline LRT & R\$66 MILLION \\
\hline HST & R \$ 67.7 MILLION \\
\hline
\end{tabular}

Table 2: Costs per km for the three railway modals (Bincoletto and Simone, 2010)

Lastly, table 3 gives an approximate idea of how many kilometers could be built, and was obtained by dividing the contribution from each source (current revenues, ICMS, IPVA CPMF) by the cost per $\mathrm{km}$ for each kind of railway transportation (as an example, with $1 \%$ of current revenues we could build $6.4 \mathrm{~km}$ annually for a light rail vehicle, $6.3 \mathrm{~km}$ for a high-speed train, and $3.3 \mathrm{~km}$ for a monorail.

\begin{tabular}{|l|l|l|l|l|}
\hline & $\begin{array}{c}\text { MUNICIPAL } \\
\text { CURRENT } \\
\text { REVENUES }\end{array}$ & \multicolumn{1}{|c|}{ IPVA } & \multicolumn{1}{|c|}{ ICMS } & \multicolumn{1}{c|}{ CPMF } \\
\hline LRT & $6.4 \mathrm{KM}$ & $13.3 \mathrm{KM}$ & $11.8 \mathrm{KM}$ & $116.1 \mathrm{KM}$ \\
\hline HST & $6.3 \mathrm{KM}$ & $13.0 \mathrm{KM}$ & $11.4 \mathrm{KM}$ & $113.2 \mathrm{KM}$ \\
\hline MONORAIL & $5.7 \mathrm{KM}$ & $11.7 \mathrm{KM}$ & $10.3 \mathrm{KM}$ & $102.1 \mathrm{KM}$ \\
\hline
\end{tabular}

Table 3: Estimate of kilometers built for each kind of railway transportation (Bincoletto and Simone, 2010)

These sums evidence that the option for rebuilding the railroad system is more political than financial, as funding can be obtained.

Use of the four sources of funding (in amounts that could be supported by the municipalities and the state government) would allow building $147.6 \mathrm{~km}$ of light rail vehicle tracks, 143.9 $\mathrm{km}$ of high-speed train tracks, and $129.8 \mathrm{~km}$ of monorails.

As we have upheld that the production of commodities embodies in the system's own concept the likelihood of crises, because all goods need to perform their salto mortale, we consider it prudent to include other forms for the system to function, apart from the production of commodities. To reduce the burden on public budgets, this great effort to rebuild the railway system could employ the work of the prison population in the state of São Paulo, which would earn less but on the other hand would have their sentences reduced, and could work as employees of public-private railroad systems.

There are other serious structural problems in Brazil, such as the system for gathering and treating sewage, which does not cover significant portions of the inhabitants of Brazilian cities and gives rise to a loss in environmental quality, as the waste is dumped in rivers; This is a problem that requires an urgent solution and the proposal outlined here could contribute with part of the funds (Basso, Pinho and Silva, 2001). 


\section{Conclusion}

If there are funds to rescue and save banks (salvage financial capital), there should be funds to save persons. As the socialism that we know has killed individual liberties and created brutal dictatorships (the Soviet Union, Cambodia, east European countries) that took the lives of millions of people, and capitalism has proved to be a perverse system that has created millions of unemployed and progressively degrades the environment, the need arises to think and propose alternatives to partly replace the production of commodities, that as Marx showed brings in its conception the likelihood crisis. The plan outlined is a proposal in this direction.

\section{Bibliography}

1. Basso, L., Pinho, F. and Da Silva, M. (2001). Tobin Tax, Minimum Income and the End of Famine in Brazil. $\begin{array}{lllll}\text { Social Science } & \text { Research } & \text { Network. } & \text { Retrieved } & \text { from }\end{array}$ http://papers.ssrn.com/sol3/papers.cfm?abstract_id=273852.

2. Basso, L., Silva, R. and Chang, S. (2005). A Marxist Theory for Exchange Rate Determination: An Empirical Investigation. Social Science Research Network. Retrieved 22.09.2012 from http://papers.ssrn.com/sol3/papers.cfm?abstract_id=457020.

3. Bincoletto, K. S. (2010). Reativação do sistema ferroviário no Brasil: custos e alternativas para o financiamento. São Paulo: Mackenzie Presbyterian University.

4. Kapoor, S. (2004). The currency transaction tax. Geneve: The Tobin Tax network. 